\title{
Response of wheat plants to sodium and calcium ion interaction under saline environment
}

\author{
${ }^{1}$ B. Zaman, ${ }^{1}$ B. H. Niazi, ${ }^{2 *}$ M. Athar and ${ }^{1}$ M. Ahmad \\ ${ }^{1}$ Institute of Natural Resources and Environmental Sciences, National Agricultural Research Center, \\ Pakistan Agricultural Research Council, Islamabad-45500, Pakistan \\ ${ }^{2}$ California Department of Food and Agriculture, 2014 Capitol Avenue, Suite 109, Sacramento, \\ CA 95814, USA
}

\begin{abstract}
Wheat being a glycophyte crop, responds differently to saline-sodic soil environmental conditions. The application of calcium is multidimensional with respect to sodium ion and plant part response. This study was conducted to record the response of shoot and root to sodium and calcium interaction under saline environment. Wheat seed of variety Punjab 85 were raised in quartz sand. Later on the seedlings were transplanted to pots containing Hoagland's nutrient solution along with $\mathrm{NaCl}$ at $0 \mathrm{mM}$. and $50 \mathrm{mM}$. Calcium was applied as $\mathrm{CaSO}_{4} 2 \mathrm{H}_{2} \mathrm{O}$ at $3 \mathrm{mM}$. and 6 mM. Under saline conditions shoot showed positive response to sodium ion in the presence of higher calcium. Relative water contents were higher in the root system at $6 \mathrm{mM}$ of $\mathrm{CaSO}_{4} \cdot 2 \mathrm{H}_{2} \mathrm{O}$ under saline condition. Growth responses to potassium and Magnesium in the presence of sodium induced salinity with calcium ion interaction remained variable.
\end{abstract}

Key words: Wheat, sodium/calcium ion, interaction, salinity

*Corresponding Author, E-mail: atariq@cdfa.ca.gov

\section{Introduction}

Wheat being a glycophyte is sensitive to tolerant under saline and saline-sodic soil environmental conditions. Rapid change in climatic conditions and deteriorating water quality are due to anthropoid behavior. This results in the selection of such cultivars of this staple food crop that can not face adverse properties of salinity and sodicity. This may include specific ion toxicity, ion imbalance, water stress and osmotic non-adjustment. Soil salinity is a global problem and results in reeduction in plant growth, reduced yield and, in severe cases, total crop failure (Qadir, et al., 2000). Of all the ions in a saline or saline-sodic medium $\mathrm{Na}^{+}$may produce detrimental effects on the availability of water in a root medium as a function of growth period and concentration in the root medium. Source of sodium ion also plays an important role in plant response to salinity. Sodium sulphate is less toxic than sodium chloride for the growth of wheat provided potassium and calcium are available in the growth medium (Zaman, et al., 2002a). Elevated level of calcium regulates and maintains potassium concentration in plants (Lauchli, 1990). Therefore the availability of macronutrients in saline or saline-sodic medium is beneficial for the yield of crops. Zaman, et al., (2002b) observed that sodium ion and dry mass are negatively correlated and application of sulphur as sulphate improves nutrient to sodium ion ratios. Salinity stress changes water permeability of the cell membrane. At high salinity level water permeability of coleoptile subepidermal cells is decreased (Mansour and Stadelmann, 1994). No visual symptoms of wilting may appear though water permeability may significantly be decreased by salinity stress. The primary effect may take place in roots due to water deficiency (Flowers and Hajibagheri, 2001). Water stress decreases water potential of tissue (Yordanov, et al., 2003). Siddique, et al. (2000) studied the effects of drought stress on water relations of wheat and observed decrease in water level under stress conditions. Physiological observations associated with the varietals difference in tolerance have been reported (Isla, et al., 1998). Keeping in view the effect of salinity on crop production, a study was conducted to observe the response of wheat plants to sodium and calcium ion interaction under saline conditions.

\section{Materials and Methods}

A hydroponic study was conducted under controlled conditions. Seeds of wheat (Triticum aestivum L. cv. Punjab 85) were germinated in 
quartz sand irrigating with distilled water. Ten days old seedlings were foam-plugged in lids of plastic pots containing 2.5L of Hoagland's nutrient solution keeping the pots continuously aerated. The light intensity was $450 \mu \mathrm{mol} \mathrm{m} \mathrm{m}^{-2} \mathrm{~s}^{-1}$. Photoperiod was adjusted to $16 \mathrm{~h}$. light period and temperature was maintained at $30 \pm 2{ }^{\circ} \mathrm{C}$. The $\mathrm{pH}$ of the solution was adjusted to 6.0 with $\mathrm{HCl}$ or $\mathrm{KOH}$ and was regularly monitored. The salinity level was $50 \mathrm{mM}$. as $\mathrm{NaCl}$, while $0 \mathrm{mM}$. $\mathrm{NaCl}$ served as control. Calcium as $\mathrm{CaSO}_{4} \cdot 2 \mathrm{H}_{2} \mathrm{O}$ was applied at 3 and $6 \mathrm{mM}$. to the pots. The salinity level ( $25 \mathrm{mM}$. ) was imposed 10 days after transplantation by incremental addition of $\mathrm{NaCl}$ at $5 \mathrm{mM}$. $\mathrm{NaCl}$ per day. The pots were arranged in complete randomized design in triplicate. The plants were harvested 44 days after sowing and their fresh weight recorded.

The plants were rinsed with deionised water and separated into root and shoot portions. Dry weight of each sample was recorded after drying at $65^{\circ} \mathrm{C}$ to constant mass. The roots and shoots were ground to pass a 40-mesh Wiley Mill and digested in 2:1 perchloric-nitric di-acid mixture. Sodium, potassium, calcium and magnesium ions in the digested material were determined by atomic absorption spectroscopy. The data were statistically analyzed according to CRD and treatment means were compared using LSD test.

\section{Results}

Growth parameters of the plants had a highly significant $(\mathrm{P}<0.01)$ effect of the treatments applied (Table 1). In the shoot, fresh weight increased by $30 \%$ with the application of $3 \mathrm{mM}$. $\mathrm{CaSO}_{4} \cdot 2 \mathrm{H}_{2} \mathrm{O}$. Fresh weight decreased by $27 \%$ with $6 \mathrm{mM}$. $\mathrm{CaSO}_{4} \cdot 2 \mathrm{H}_{2} \mathrm{O}$ in treatment without salinity. In the presence of $50 \mathrm{mM}$. NaCl, fresh weight decreased by $2 \%$ with the application of $3 \mathrm{mM}$. $\mathrm{CaSO}_{4} \cdot 2 \mathrm{H}_{2} \mathrm{O}$ and it increased by $102 \%$ with $6 \mathrm{mM}$. $\mathrm{CaSO}_{4} \cdot 2 \mathrm{H}_{2} \mathrm{O}$.

In root it increased by $188 \%$ and $31 \%$ with application of $3 \mathrm{mM}$. and $6 \mathrm{mM}$. $\mathrm{CaSO}_{4} \cdot 2 \mathrm{H}_{2} \mathrm{O}$ respectively, without salinity.
In the presence of $50 \mathrm{mM}$. $\mathrm{NaCl}$, fresh weight increased by 73 and $125 \%$ with application of $3 \mathrm{mM}$. and $6 \mathrm{mM}$. $\mathrm{CaSO}_{4} \cdot 2 \mathrm{H}_{2} \mathrm{O}$ respectively.

In the shoot, dry matter (DM) increased by $15 \%$ with the application of $3 \mathrm{mM}$. $\mathrm{CaSO}_{4} \cdot 2 \mathrm{H}_{2} \mathrm{O}$, and it decreased by $23 \%$ with $6 \mathrm{mM}$. $\mathrm{CaSO}_{4} \cdot 2 \mathrm{H}_{2} \mathrm{O}$ applied in the plants without salinity (Table 2). In the presence of $50 \mathrm{mM}$. NaCl, DM increased by 13 and $75 \%$ with the application of $3 \mathrm{mM}$. $\mathrm{CaSO}_{4} \cdot 2 \mathrm{H}_{2} \mathrm{O}$ and $6 \mathrm{mM}$. $\mathrm{CaSO}_{4} \cdot 2 \mathrm{H}_{2} \mathrm{O}$ respectively. In the root, DM increased by $3 \%$ with $3 \mathrm{mM}$. $\mathrm{CaSO}_{4} \cdot 2 \mathrm{H}_{2} \mathrm{O}$ and decreased by $37 \%$ with $6 \mathrm{mM}$. $\mathrm{CaSO}_{4} \cdot 2 \mathrm{H}_{2} \mathrm{O}$ without salinity. In the presence of $50 \mathrm{mM}$. $\mathrm{NaCl}, \mathrm{DM}$ increased by $12 \%$ with $3 \mathrm{mM}$. $\mathrm{CaSO}_{4} \cdot 2 \mathrm{H}_{2} \mathrm{O}$ and decreased by $76 \%$ with $6 \mathrm{mM}$. $\mathrm{CaSO}_{4} \cdot 2 \mathrm{H}_{2} \mathrm{O}$. As per ascending order, in shoot, the sequence of relative water content (RWC) as given in Figure 1 given as: $3 \mathrm{mM}$. $\mathrm{CaSO}_{4} \cdot 2 \mathrm{H}_{2} \mathrm{O}$ with salinity, $3 \mathrm{mM}$.

$\mathrm{CaSO}_{4} \cdot 2 \mathrm{H}_{2} \mathrm{O}$ without salinity, $6 \mathrm{mM}$. $\mathrm{CaSO}_{4} \cdot 2 \mathrm{H}_{2} \mathrm{O}$ with out salinity, salinity, control. Relative water content in root in the same sequence was: control, salinitz, $6 \mathrm{mM}$. $\mathrm{CaSO}_{4} \cdot 2 \mathrm{H}_{2} \mathrm{O}, 3 \mathrm{mM}$. $\mathrm{CaSO}_{4} \cdot 2 \mathrm{H}_{2} \mathrm{O}, 3 \mathrm{mM}$. CaSO${ }_{4} \cdot 2 \mathrm{H}_{2} \mathrm{O}$ with salinity, 6 $\mathrm{mM}$. $\mathrm{CaSO}_{4} \cdot 2 \mathrm{H}_{2} \mathrm{O}$ with salinity. A comparison between shoot and root showed that at $6 \mathrm{mM}$ $\mathrm{CaSO}_{4} \cdot 2 \mathrm{H}_{2} \mathrm{O}$ applied in the presence of salinity RWC was higher in the root system. Expansion of growth was higher in root than shoot at $6 \mathrm{mM}$ $\mathrm{CaSO}_{4} \cdot 2 \mathrm{H}_{2} \mathrm{O}$ in the presence of salinity. In shoot, in the absence of salinity with the application of 3 $\mathrm{mM}$. $\mathrm{CaSO}_{4} \cdot 2 \mathrm{H}_{2} \mathrm{O}$ potassium concentration $(2.20$ DM) was the highest (Figure 2) and its concentration was lowest $(1.02 \mathrm{mg} / \mathrm{g} \mathrm{DM})$ in the presence of salinity. In root, in the absence of salinity with the application of $3 \mathrm{mM}$. $\mathrm{CaSO}_{4} \cdot 2 \mathrm{H}_{2} \mathrm{O}$, potassium concentration $(5.40 \mathrm{mg} / \mathrm{gDM})$ was the highest and on the induction of salinity alone its concentration was lowest $(4.76 \mathrm{mg} / \mathrm{g} \mathrm{DM})$. In the absence of salinity in shoot, calcium concentration $(7.93 \mathrm{mg} / \mathrm{g}$ DM) was the highest (Figure 2) and in the presence of salinity its concentration was lowest $(1.53 \mathrm{mg} / \mathrm{g}$ $\mathrm{DM}$ ) on the application of $3 \mathrm{mM}$. $\mathrm{CaSO}_{4} \cdot 2 \mathrm{H}_{2} \mathrm{O}$.

Table 1: Fresh mass of wheat shoot and root with the application of $\mathrm{CaSO}_{4} \cdot 2 \mathrm{H}_{2} \mathrm{O}$ under sodic and non sodic application

\begin{tabular}{|c|cccccc|}
\hline \multirow{2}{*}{$\begin{array}{c}\mathrm{CaSO}_{4} .2 \mathrm{H}_{2} \mathrm{O} \\
(\mathrm{mM} .)\end{array}$} & \multicolumn{3}{c|}{ Shoot } & \multicolumn{3}{c|}{ Root } \\
\cline { 2 - 7 } & & \multicolumn{5}{c|}{ NaCl $(\mathrm{mM})$} \\
Control & $0 \mathrm{mM}$. & $50 \mathrm{mM}$. & Means & $0 \mathrm{mM}$. & $50 \mathrm{mM}$. & Means \\
3 & $3.12 \mathrm{c}$ & $1.77 \mathrm{f}$ & $2.45 \mathrm{~B}$ & $0.89 \mathrm{e}$ & $0.83 \mathrm{f}$ & $0.86 \mathrm{C}$ \\
6 & $4.07 \mathrm{a}$ & $1.80 \mathrm{e}$ & $2.94 \mathrm{~A}$ & $2.56 \mathrm{a}$ & $1.44 \mathrm{c}$ & $2.00 \mathrm{~A}$ \\
Means & $2.29 \mathrm{~d}$ & $3.58 \mathrm{~b}$ & $2.94 \mathrm{~A}$ & $1.17 \mathrm{~d}$ & $1.87 \mathrm{~b}$ & $1.52 \mathrm{~B}$ \\
\end{tabular}

Means sharing similar letter(s) in columns for shoot and root do not differ significantly at $\mathrm{p}<0.01$ 


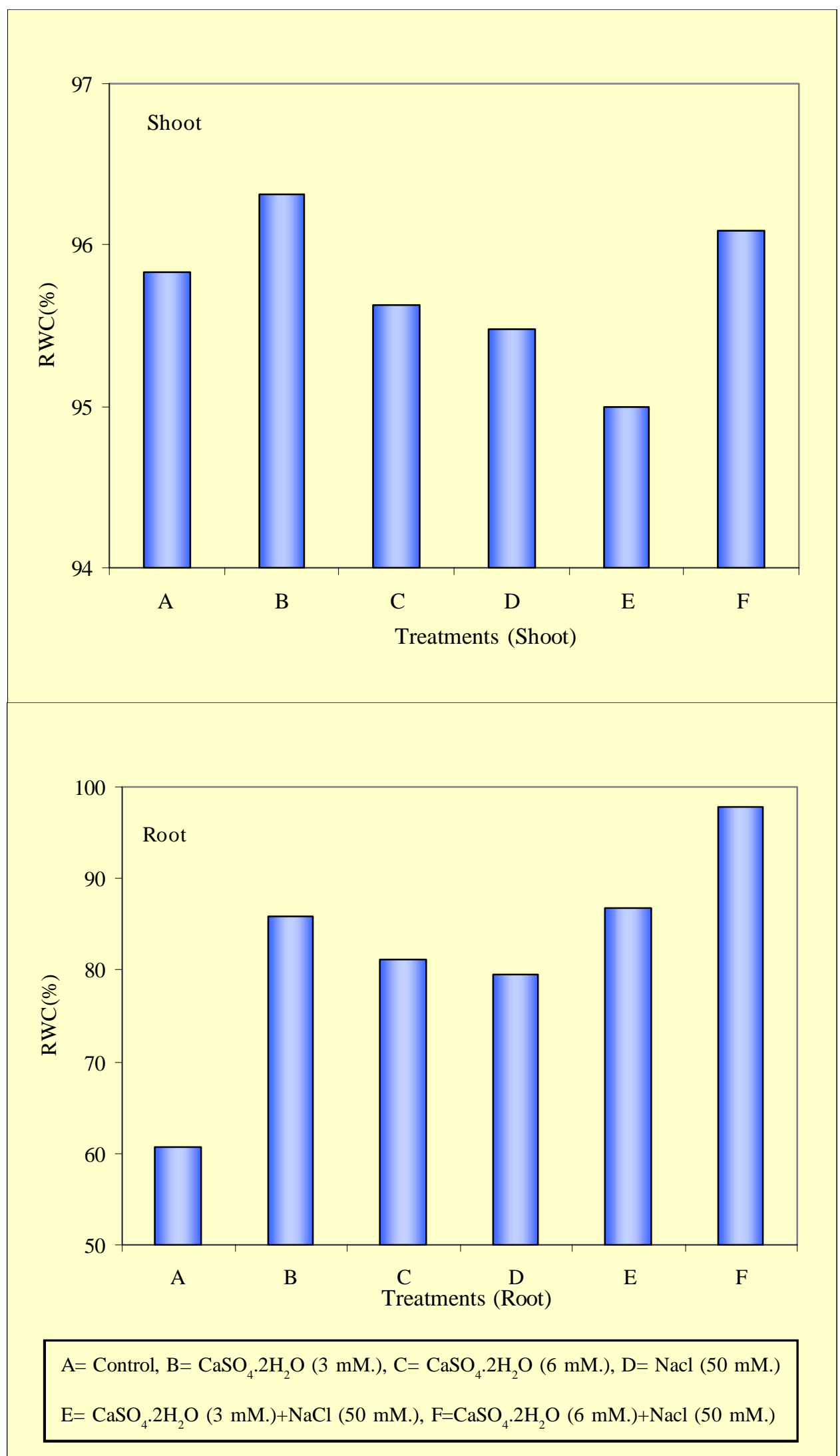

Figure 1: Relative contents of water as affected by sodium with calcium application in wheat 
B. Zaman, et al.

Table 2: Dry mass of wheat shoot and root with the application of $\mathrm{CaSO}_{4}$. $2 \mathrm{H}_{2} \mathrm{O}$ under sodic and non sodic application

\begin{tabular}{|c|cccccc|}
\hline \multirow{2}{*}{$\begin{array}{c}\mathrm{CaSO}_{4} .2 \mathrm{H}_{2} \mathrm{O} \\
(\mathrm{mM} .)\end{array}$} & \multicolumn{3}{|c|}{ Shoot } & \multicolumn{2}{c|}{ Root } \\
\cline { 2 - 7 } & & \multicolumn{5}{c|}{$\mathrm{NaCl}(\mathrm{mM})}$. \\
Control & $0 \mathrm{mM}$. & $50 \mathrm{mM}$. & Means & $0 \mathrm{mM}$. & $50 \mathrm{mM}$. & Means \\
3 & $0.13 \mathrm{c}$ & $0.08 \mathrm{f}$ & $0.11 \mathrm{~B}$ & $0.35 \mathrm{~b}$ & $0.17 \mathrm{e}$ & $0.26 \mathrm{~B}$ \\
6 & $0.15 \mathrm{a}$ & $0.09 \mathrm{e}$ & $0.12 \mathrm{~A}$ & $0.36 \mathrm{a}$ & $0.19 \mathrm{~d}$ & $0.28 \mathrm{~A}$ \\
Means & $0.10 \mathrm{~d}$ & $0.14 \mathrm{~b}$ & $0.12 \mathrm{~A}$ & $0.22 \mathrm{c}$ & $0.04 \mathrm{f}$ & $0.13 \mathrm{C}$ \\
\hline
\end{tabular}

Means sharing similar letter(s) in columns for shoot and root do not differ significantly at $\mathrm{p}<0.01$
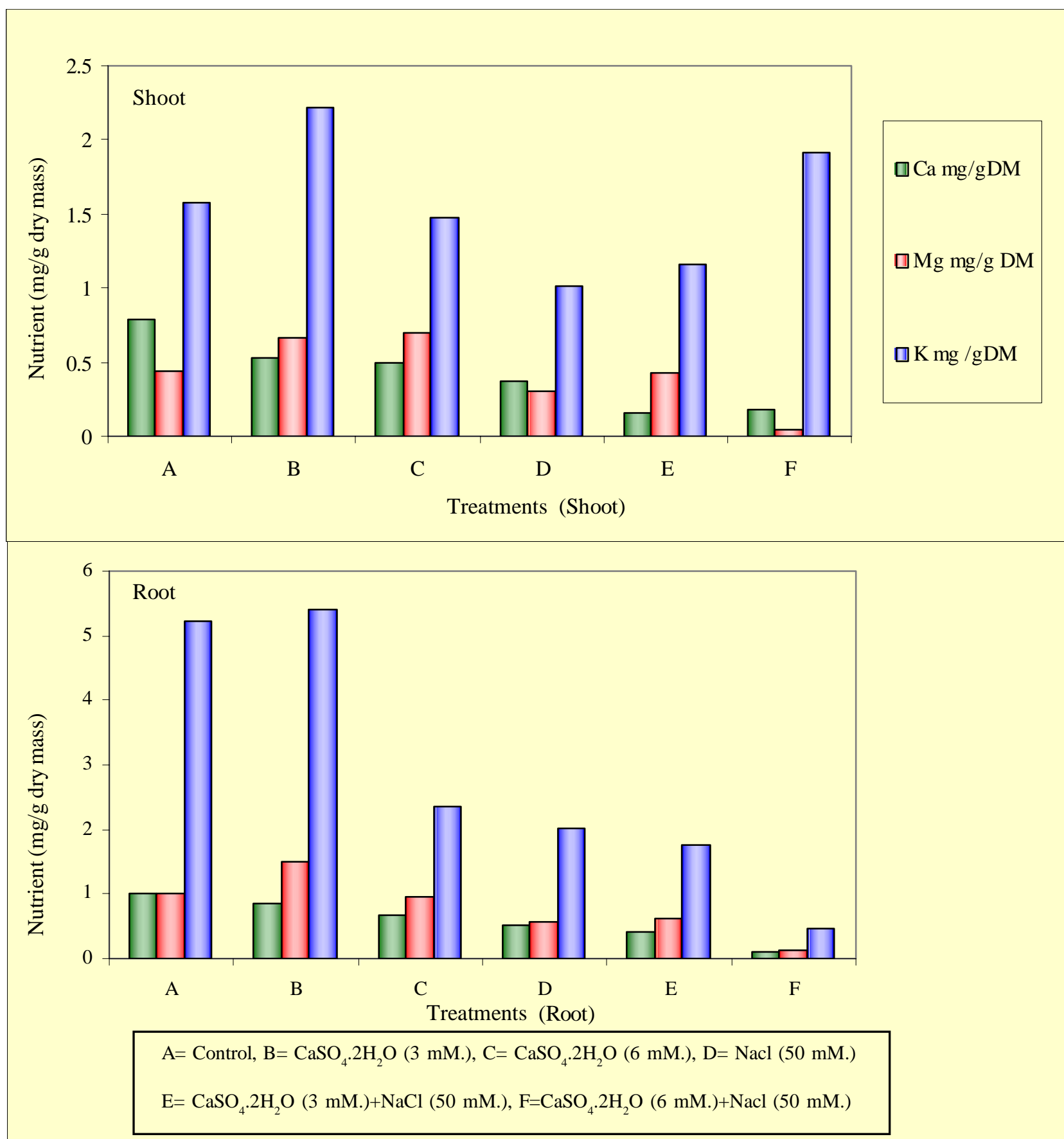

Figure 2: Effect of different treatments on the nutrient concentration in wheat under CaSO4.2H2 application with and without sodium ion 
In root, in the absence of salinity, calcium concentration (1.02 mg/g DM) was the highest and on the application of salinity alone its concentration was lowest $(0.10 \mathrm{mg} / \mathrm{g} \mathrm{DM})$.

In shoot, in the absence of salinity magnesium concentration $(7.70 \mathrm{mg} / \mathrm{g} \mathrm{DM})$ was highest and its concentration was lowest $(0.05 \mathrm{mg} / \mathrm{g} \mathrm{DM})$ on the application of $6 \mathrm{mM}$. CaSO $\mathrm{C}_{4} \cdot 2 \mathrm{H}_{2} \mathrm{O}$ in the presence of salinity. In root, in the absence of salinity and with the application of $3 \mathrm{mM}$. $\mathrm{CaSO}_{4} \cdot 2 \mathrm{H}_{2} \mathrm{O}$, calcium concentration $(1.51 \mathrm{mg} / \mathrm{g} \mathrm{DM})$ was the highest and its concentration was lowest $(1.40 \mathrm{mg} / \mathrm{g} \mathrm{DM})$ on the application of $6 \mathrm{mM}$. $\mathrm{CaSO}_{4} \cdot 2 \mathrm{H}_{2} \mathrm{O}$ in the presence of salinity.

\section{Discussion and Conclusion}

Physiologically, growth is a function of different kinds and levels of salts applied in the root medium. The excess of $\mathrm{Ca}$ ion in the medium causes retardation in the growth of shoot whereas in the saline medium when sodium ion is available, the abundance of $\mathrm{Ca}$ ion is required to check the toxic activities of $\mathrm{Na}$ ion. Ebert, et al. (2002) pointed out that cation relations in the shoot tissue such as $\mathrm{Ca}^{+2} /$ $\mathrm{Na}^{+}$have possessed a strong influence on salt tolerance than absolute sodium levels. Presence of higher level of $\mathrm{Ca}^{+2}$ induced signals and the concentration difference across the plasma membrane results in a very steep electrochemical gradient in favor of $\mathrm{Ca}^{+2}$ influx. Availability of $\mathrm{Ca}^{+2}$ in the external environment ameliorate $\mathrm{NaCl}$ stress (Zhong and Lauchli, 1994). Therefore, amount of available $\mathrm{Ca}^{+2}$ is also important. Higher level of calcium application $\left(6 \mathrm{mM} \cdot \mathrm{CaSO}_{4} \cdot 2 \mathrm{H}_{2} \mathrm{O}\right)$ contributed towards salinity resistance. The contribution of such salts may not be toxic but play some important role for checking the water potential of plant which ultimately results in reduction of metabolites for the synthesis of biomass. A comparison between shoot and root showed that at $6 \mathrm{mM}$. $\mathrm{CaSO}_{4} \cdot 2 \mathrm{H}_{2} \mathrm{O}$ applied in the presence of salinity, RWC was higher in the root system. Expansion of growth was higher in root than shoot at $6 \mathrm{mM}$. $\mathrm{CaSO}_{4} \cdot 2 \mathrm{H}_{2} \mathrm{O}$ in the presence of salinity. This indicates that the presence of excessive amount of $\mathrm{Ca}$ ions contribute to decrease the toxic effects of salinity by enhancing tissue growth. The leaf water potential evaluates the water-stress intensity sensed by leaves (Hsiao, 1973). An important factor limiting the potential tolerance of all wheat varieties may be the high unidirectional influx of $\mathrm{Na}^{+}$into the root, which is very similar in both tolerant and sensitive varieties (Davis, 1984 and Davenport, et al., 1997). Salt tolerance has been associated with preferential accumulation of $\mathrm{K}^{+}$against high $\mathrm{Na}^{+}$(Badr, et al., 2002a). Selectivity of $\mathrm{K}^{+} / \mathrm{Na}^{+}$is improved by the presence of $\mathrm{Ca}^{+2}$ (Cramer, et al., 1985). Preference of $\mathrm{K}^{+} / \mathrm{Na}^{+}$may be due to genetic factor (Greenway and Munns, 1980). The results show that organ preference for $\mathrm{K}^{+}$over $\mathrm{Na}^{+}$is also dependent on $\mathrm{Ca}^{+2}$ in the growth medium. Minhas, (1996) suggested that adverse effects of high sodium on the physical and chemical properties of soils can be mitigated by the use of different amendments, which contain soluble calcium e.g., gypsum. It is also suggested by Leopold and Willing (1984) that application of external calcium has been known to ameliorate salinity stress symptoms in many plant species. Lynch and Lauchi (1985) pointed out that $\mathrm{Na}^{+}$concentration in root medium may induce calcium deficiency in plants grown with low calcium. Kinraide (1998) reported that main effect of $\mathrm{Ca}^{+2}$ on the $\mathrm{Na}^{+}$uptake at high $\mathrm{Ca}^{+2}$ concentration was the electrostatic displacement of $\mathrm{Na}^{+}$from plasma membrane surface. Maathuis and Amtmaan (1999) concluded that direct effect of $\mathrm{Ca}^{+2}$ on the movement of $\mathrm{Na}^{+}$is manifested in voltage independent channels. Positive correlations were also reported for species tolerant to stresses that have a dehydrative component such as salt stress (Galvez, et al., 1993; Moons, et al., 1995).

In the presence of salinity with the application of $\mathrm{Ca}^{+2}$ ion, the nature of salinity and the intensity changes that may cause a change to RWC as well as nutrient status in aerial and non aerial wheat plant parts. In wheat at $50 \mathrm{mM}$. of sodium induced salinity, the application of $6 \mathrm{mM}$. $\mathrm{CaSO}_{4} \cdot 2 \mathrm{H}_{2} \mathrm{O}$ reduces the osmotic effects.

\section{References}

Cramer, G. R., A. Lauchli, and V. S. Polito, Displacement of $\mathrm{Ca}^{+2}$ by $\mathrm{Na}^{+}$from plasmalemma of root cells. A primary response to salt stress? Plant Physiol., 79: 207-211, 1985

Davenport, R. J., R. J. Reid, F. A. Smith, Sodium-calcium interactions in two wheat species differing in salinity tolerance. Plant Physiol., 99: 323-327, 1997

Davis, $R$. F., Sodium fluxes in intact roots of wheat varieties differing in salt tolerance. In: W. J. Cram, K. Janácek, R. Rybova and K. Sigler, (Eds.), Membrane Transport in Plants. Wiley, Chichester, UK: 489-490, 1984 
Ebert, G. J., H. Eberle, D. Ali and P. Ludders, Ameliorating effects of $\mathrm{Ca}\left(\mathrm{NO}_{3}\right)_{2}$ on growth, mineral uptake and photosynthesis of NaCl-stressed guava seedling (Psidium guajava L.). Scienta. Hort., 93:125135, 2002

Flowers, T. J. and M. A. Hajibagheri, Salinity tolerance in Hordeum vulgare: ion concentrations in root cells of cultivars differing in salt tolerance. Plant Soil, 231:1-9, 2001

Galvez, A. F., P. J. Gulick and J. Dvorak, Characterization of the early stages of genetic saltstress responses in salt-tolerant Lophopyrum elongatum, salt-sensitive wheat, and their amphiploid. Plant Physiol., 103: 257-265, 1993

Gorham, J., A. Bristol, E. M. Young, R. G. Wyn Jones and G. Kashour, Salt tolerance in the Triticeae: $\mathrm{K} / \mathrm{Na}$ discrimination in barley. J. Exp. Bot., 41:1095-1101, 1990

Isla, R., R. Aragues and A. Royo, Validity of various physiological traits as screening criteria for salt tolerance in barley. Field crops Res. 58: 97-107, 1998

Kinraide, T. B., Three mechanisms for calcium alleviation of mineral toxicities. Plant Physiol., 118: 513-520, 1998

Lauchli, A., Calcium, salinity and plasma membrane. In: R. T. Leonard and P. K. Hepler (Eds.). Calcium in Plant Growth and Development. Am. Soc. Plant Physiol., Rockville. MD: 26-35, 1990

Leopold, A. C. and R. P. Willing, Evidence for toxicity effects of salts on membranes. In: R. C. Staples and G. H. Toenniessen (Eds.), Salinity Tolerance in Plants. John Wiley and Sons, New York: 67-76, 1984

Lynch, J. and A. Lauchli, Salt stress disturbs the calcium nutrition of barley (Hordeum vulgare L). New Phytol., 99: 45-354, 1985

Maathuis, J. M. F and A. Amtmaan, $K^{+}$nutrition and $\mathrm{Na}^{+}$toxicity: The basis of cellular $\mathrm{K}^{+} / \mathrm{Na}^{+}$ratios. Ann. Bot., 84: 123-133, 1999
Mansour, M. M. F. and E. J. Stadelmann, NaCl-induced changes in protoplasmic characteristics of Hordeum vulgare cultivars differing in salt tolerance. Plant Physiol., 91: 389-394, 1994

Minhas, P. S., Saline water management for irrigation in India. Rev. Agric. Water Manage., 28: 273-288, 1996

Moons, A. G., E. Bauw, E. Prinsen, M. Van Montagu and $D$. Van der Straeten, Molecular and physiological responses to abscisic acid and salts in roots of saltsensitive and salt-tolerant indica rice varieties. Plant Physiol., 107: 177-186, 1995

Qadir, M. A. Ghafoor and G. Murtaza, Amelioration strategies for saline soils: a review. Land Degrad. Develop., 11:501-521, 2000

Siddique, M. R. B., A. Hamid and M. S. Islam, Drought stress effects on water relations of wheat. Bot. Bull. Acad. Sin., 41:35-39, 2000

Yordanov, I., V. Velikova and T. Tsonev, Plant responses to drought and stress tolerance. Bulg.J. Plant Physiol., Spec. Issue:187-206, 2003

Zaman, B., A. Ali, M. Salim and K. Hussain, Growth of wheat as affected by sodium chloride and sodium sulphate salinity. Pak. J. Biol. Sci., 5: 1313-1315, $2002 a$

Zaman, B., A. Ali, M. Salim and B.H. Niazi, Role of sulphur for potassium/ sodium ratio in sunflower under saline conditions. Helia, 25: 69-78, $2002 b$

Zhong, H. and A. Lauchli, Spatial distribution of solutes, $\mathrm{K}, \mathrm{Na}$, Ca and their deposition rates in the growth zone of primary cotton roots: Effect of $\mathrm{NaCl}$ and $\mathrm{CaCl}_{2}$ Planta, 194: 34-41, 1994 